\title{
Non-alcoholic fatty liver disease in patients with familial hypercholesterolemia
}

\section{Ailevi hiperkolesterolemisi olan kişilerde non-alkolik yağlı karaciğer hastalığı}

\author{
Aynur Arslan ${ }^{1 *}$ (D) Özgür Şimşek ${ }^{2}$ (D), Aykut Turhan ${ }^{3}$ (D), Ayşe Çarlıoğlu ${ }^{4}$ (D), Şenay Arıkan ${ }^{5}$ (D), \\ Mustafa Utlu ${ }^{2}$ (D), Emine Kartal Baykan ${ }^{6}$ (D) \\ ${ }^{1}$ Internal Medicine Specialist, Istinye State Hospital, Istanbul, Turkey \\ ${ }^{2}$ Internal Medicine Specialist, Erzurum Regional Training and Research Hospital, Erzurum, Turkey \\ ${ }^{3}$ Internal Medicine Specialist, Askale State Hospital, Erzurum, Turkey \\ ${ }^{4}$ Prof Dr, Endocrinology Clinic of Lokman Hekim Hospital, Ankara, Turkey \\ ${ }^{5}$ Prof Dr, Endocrinology Clinic of Kirikkale University, Kirikkale, Turkey \\ ${ }^{6}$ Endocrinology Clinic of Erzurum Regional Training and Research Hospital, Erzurum, Turkey \\ * Corresponding author: Aynur Arslan E-mail: aynurarslan2001@yahoo.com ORCID: 0000-0001-5968-5823 \\ Received: 14 Ocak 2020 Accepted: 12 Mart 2020
}

\begin{abstract}
Aim: The liver plays a crucial role in the synthesis and catabolism of cholesterol. Non-alcoholic fatty liver disease (NAFLD) is the most common cause of chronic liver disease in the developed world and commonly associated with metabolic comorbidities such as diabetes mellitus, hypertension, dyslipidemia, and obesity. The aim of this study was to investigate the frequency of NAFLD in Familial Hypercholesterolemia (FH).

Material and Method: Between 2017 and 2018, individuals with FH who had been referred to the Department of Endocrinology at Erzurum Regional Training and Research Hospital were admitted to this single center case-control study. Total 30 individuals ( 17 female and 13 male) who have $\mathrm{FH}$ were compared to a control group included 39 participants ( 30 female and 9 male). The two groups were thought to be well matched in terms of sample size and gender distribution. Family history was registered. Diagnosis is made by blood tests and ultrasound imaging of liver.

Results: The two groups showed no significant differences in terms of age and gender. NAFLD was seen at 12 of 39 individuals in the control group. It was seen at 16 of 30 persons in the FH group $(p=0.058)$. Total cholesterol $(\mathrm{mg} / \mathrm{dl})(333.27$ $\pm 58.46)(219.23 \pm 82.84)(p=0.000), L D L(m g / d l)(249.93 \pm 45.43)(127.11 \pm 46.52)(p=0.000)$ and CRP $(\mathrm{mg} / \mathrm{L})(3.37 \pm 4.16)$ $(1.43 \pm 1.96)(p=0.014)$ levels were significantly different between the $\mathrm{FH}$ and control groups respectively.

Conclusion: There isn't a significant difference between control and FH groups in terms of NAFLD. The absence of NAFLD on ultrasonography, should not reduce the severity and importance of $\mathrm{FH}$, and the treatments should be made to prevent complications such as atherosclerosis.
\end{abstract}

Keywords: hypercholesterolemia, non-alcoholic fatty liver disease, ultrasonography 


\section{ÖZ}

Amaç: Karaciğer, kolesterol sentezinde ve katabolizmasında çok önemli rol oynar. Non-alkolik yağlı karaciğer hastalığı (NAYKH), gelişmiş ülkelerde kronik karaciğer hastalığının en sık sebebidir ve sıklıkla diabetes mellitus, hipertansiyon, dislipidemi ve obezite gibi metabolik hastalıklarla komorbidite gösterir. Bu çalışmanın amacı Ailevi Hiperkolesterolemide (AH) NAYKH görülme sıklığını araştırmaktır.

Gereç ve Yöntemler: 2017-2018 yılları arasında Erzurum Bölge Eğitim ve Araştırma Hastanesi Endokrinoloji Polikliniğine başvurmuş olan AH'li kişiler tek merkezli bu vaka kontrol çalışmasına alındı. AH'li toplam 30 kişi (17 Kadın 13 erkek), 39 kişiden oluşan (30 kadın, 9 erkek) kontrol grubu ile karşılaştırıldı. İki grup sayı ve cinsiyet yönünden denkti. Aile öyküsü kaydedildi. Tanı kan tetkikleri ve karaciğer ultrasonografisi ile kondu.

Bulgular: Ikki grup arasında yaş ve cinsiyet açısından anlamlı fark görülmedi. NAYKH, kontrol grubundaki 39 kişiden 12 'sinde saptanırken, $\mathrm{AH}$ grubunda 30 kişiden 16 'sında görüldü $(\mathrm{p}=0,058)$. AH ve kontrol gruplarının sırasıyla toplam kolesterol $(333,27 \pm 58,46)(219,23 \pm 82,84)(\mathrm{mg} / \mathrm{dl})(\mathrm{p}=0,000), \operatorname{LDL}(249,93 \pm 45,43)(127,11 \pm 46,52)(\mathrm{mg} / \mathrm{dl})(\mathrm{p}=0,000)$ ve CRP $(3,37$ $\pm 4,16)(1,43 \pm 1,96)(\mathrm{mg} / \mathrm{L})(\mathrm{p}=0,014)$ düzeyleri arasında anlamlı fark bulundu.

Sonuçlar: AH ve kontrol grupları arasında NAYKH açısından anlamlı bir fark yoktur. Ultrasonografide NAYKH saptanmaması, AH'ye yaklaşımdaki ciddiyeti azaltmamalıdır.

Anahtar kelimeler: hiperkolesterolemi, non alkolik yağlı karaciğer hastalığı, ultrasonografi

\section{INTRODUCTION}

Lipoproteins are essential for transport of cholesterol, triglycerides, and fat soluble vitamins through body fluids to and from tissues. Disorders of lipoprotein metabolism are called as dyslipidemias. If the levels of LDL are very high, it is likely genetic.

Familial hypercholesterolemia (FH) is a common and serious autosomal dominant disorder that leads to aggressive and premature atherosclerosis, although there is not a unique gene involved. The diagnosis is performed using lipid phenotype, physical stigmata, for example, tendon xanthomas and familial history of hyperlipidemia. $\mathrm{FH}$ is one of the most frequently occurring Mendelian disorders, representing about 1 in 500 individuals. More than 1600 different mutations have been reported in association with $\mathrm{FH}$. As a consequence of a mutation in the LDL-receptor gene, impaired transport of LDL into the cells results in a reduced rate of clearance of LDL from the circulation and causes hypercholesterolemia [1].

NAFLD is the leading cause of chronic liver disease in USA, affecting nearly a third of the US population [2]. It is estimated that around 64 million people in USA have NAFLD, with annual direct medical costs of about US $\$ 103$ billion (US \$ 1613 per patient) [3]. NAFLD may be considered the hepatic event in the metabolic syndrome and is therefore linked with common metabolic syndrome risk factors such as obesity, insulin resistance, hypertension, and dyslipidemia [4]. FH is characterized by elevated plasma levels of LDL (usually 200-400 mg / dL) in the absence of hypertriglyceridemia [5]. Disease recognition is usually based on detection of hypercholesterolemia on routine screening. Elevated levels of cholesterol lead to tendinous xanthomas and coronary, cerebral, and peripheral vascular atherosclerosis at an early age. Untreated $\mathrm{FH}$ is associated with an increased risk of cardiovascular disease. A familial history of hyperlipidemia and / or premature coronary disease is supportive of the diagnosis. Diagnosis is usually made on clinical grounds.

Approximately $70 \%$ of the plasma LDL is cleared by the liver. In this process the first step involves binding of LDL to cell surface receptors.

NAFLD is the most common acquired metabolic disorder and affects $3-12 \%$ of western population. NAFLD is strongly associated with overweight / obesity and insulin resistance. NAFLD is found to increase the risk for hepatocellular carcinoma. Over the past 15 years, NAFLD is the most common cause of elevated liver enzymes found in the population [6]. Ethnicity affects the prevalence of NAFLD. In pathogenesis, insulin resistance and hepatocellular oxidative injury takes place. Individuals with insulin resistance and metabolic syndrome, the visceral adipose tissue increases and becomes dysfunctional. Adiponectin production reduces, and inflammatory cytokines production increases. Fat laden cells are easily damaged by oxidative stress causing apoptosis. There isn't any specific blood test for NAFLD. Subjects with NAFLD are usually asymptomatic. 
The term "Nonalcoholic steatohepatitis" (NASH) is preferred to use for histologic features of hepatocyte injury [7]. The majority of hepatocellular lipids are stored as triglycerides, but free fatty acids, cholesterol, and phospholipids, may contribute. In NASH triglyceride accumulation and inflammation coexists. Pathologic steatosis is defined as involving more than $5 \%$ of hepatocytes. NASH involves liver lipid accumulation (steatosis) combined with hepatic inflammation. Individuals with simple steatosis are generally asymptomatic. Abdominal ultrasound imaging may reveal fat accumulation in the liver. Serum ALT AST are elevated in about $90 \%$ with NASH. Liver biopsy is the most reliable diagnostic tool.

The prevalence of NAFLD in the general population is increasing, but only a small proportion will develop NASH. Estimates in the United States are that only $2 \%-3 \%$ of all adults have $\mathrm{NASH}$, compared with an estimation of $20 \%$ of Americans with NALFD [8].

Pathogenesis of NAFLD: When hepatocyte mechanisms for triglyceride synthesis such lipid uptake and lipogenesis overwhelm mechanisms for triglyceride disposal such degradative metabolism and lipoprotein export lead to accumulation of fat within hepatocytes. There isn't any specific blood test for NAFLD. Subjects with NAFLD are usually asymptomatic.

Diagnosis of NAFLD is made when abnormal liver aminotransferases or features of fatty liver are noted during an evaluation performed for other reasons. Obesity and other features of metabolic syndrome such as hypertriglyceridemia, low levels of $\mathrm{HDL}$, hyperglycemia, and hypertension are present in most patients.

The aim of this study was to investigate the frequency of NAFLD in FH.

\section{MATERIAL AND METHODS}

Between 2017 and 2018, individuals with $\mathrm{FH}$ who had been referred to the Department of Endocrinology at Erzurum Regional Training and Research Hospital were admitted to this case-control study. Total 30 individuals (17 female and 13 male) who have $\mathrm{FH}$ were compared to a control group included 39 participants ( 30 female and 9 male). The mean age was $49.16 \pm 11.63$ in the study group and $45.97 \pm 8.073$ in the control group. The two groups were thought to be well matched in terms of sample size and gender distribution. A careful social, medical and family history obtained. Family history of cardiovascular disease (firstdegree relatives: males younger than 55 years, females younger than 60 years) was also registered. Diagnosis was made by blood tests and ultrasound imaging of liver.

Biochemical and hormone analysis. Fasting blood samples were collected in gel tubes that did not include anticoagulants to measure blood glucose, cholesterol, Creactive protein (CRP), thyroid stimulating hormone (TSH), free T3 (FT3), free T4 (FT4), thyroid peroxidase immune body (anti-TPO), anti-thyroglobulin immune body (anti-TG), and liver and renal function. An additional blood sample was collected in an EDTA tube and used to measure the hemogram. All the blood samples were collected after $12 \mathrm{~h}$ overnight fasting and centrifuged at $1800 \times \mathrm{g}$ for $15 \mathrm{~min}$ before analyzing.

Biochemical parameters were measured colorimetrically using Abbott original reagents in an Abbott Architect c8000 autoanalyzer. Plasma lipid and lipoprotein levels were measured after a 12-h overnight fast. The total cholesterol and triglyceride levels in the plasma were measured enzymatically. After precipitation of apoB containing lipoproteins, HDL was measured. LDL was estimated by using following equation:

$\mathrm{LDL}=$ total cholesterol $-(\mathrm{TG} / 5)-\mathrm{HDL}$

Hypothyroidism, nephrotic syndrome, obstructive liver disease, viral hepatitis, excessive alcohol consumption, drug-induced or congenital liver diseases, surgical procedures (gastric by pass, extensive small bowel resection, jejunoileal by pass), autoimmune diseases, pregnancy, inborn errors of metabolism, medications associated with hepatic steatosis excluded.

Clinical Research approval was received for this study from the Local Ethics Committee of Erzurum Regional Training and Research Hospital. World Medical Association Declaration of Helsinki Ethical Principles for Medical Research Involving Human Subjects were applied in this study.

A hepatic USG examination was performed by the radiologists. NAFLD was defined as an increase at the liver echogenicity and graded from 1 to 3 . The normal liver parenchyma has a homogeneous echogenicity equal to the renal cortex and spleen.

Grade 1: Increased diffuse echogenicity,

Grade 2: The portal vein branches and diaphragm echogenicity were partly obscured by the increased parenchyma echogenicity. 
Table 1. Total cholesterol (mg / dl), LDL (mg / dl) and CRP (mg / L) levels were significantly different between the familial hypercholesterolemia $(\mathrm{FH})$ and control groups

\begin{tabular}{|c|c|c|c|}
\hline & FH (mean \pm SD) & Control (mean \pm SD) & p-values \\
\hline Total cholesterol & $333.27 \pm 58.46$ & $219.23 \pm 82.84$ & 0.000 \\
\hline LDL & $249.93 \pm 45.43$ & $127.11 \pm 46.52$ & 0.000 \\
\hline CRP & $3.37 \pm 4.16$ & $1.43 \pm 1.96$ & 0.014 \\
\hline
\end{tabular}

$\mathrm{FH}$ : familial hypercholesterolemia

Table 2. The ultrasound imaging of liver of the familial hypercholesterolemia $(\mathrm{FH})$ and control groups $(p=0.058)$

\begin{tabular}{|c|c|c|}
\hline & FH & Control \\
\hline NAFLD & 16 & 12 \\
\hline Normal liver ultrasound & 23 & 27 \\
\hline
\end{tabular}

NAFLD: Non-alcoholic fatty liver disease.

Grade 3: The diaphragmatic outline was not visualized, and the posterior segments of the liver were poorly assessed [9].

\section{STATISTICAL ANALYSIS}

We performed all statistical analyses using SPSS for Windows, version 17.0. Unless otherwise stated, results were expressed as mean $\pm \mathrm{SD}$. We used the Mann-Whitney $U$ test or independent sample t test between two subject groups, and used the Pearson correlation test or Spearman correlation test, as appropriate. A p value less than 0.05 was considered statistically significant.

Informed consent statement: All involved persons (subjects or legally authorized representative) gave their informed consent prior to study inclusion.

Conflict-of-interest statement: There isn't any conflict-ofinterest statement.

Data sharing statement: Presented data are anonymized and risk of identification is low.

\section{RESULTS}

Serum AST, ALT, and creatinine levels of FH group were not higher than control group, but total cholesterol (mg / dl) $(333.27 \pm 58.46)(219,23 \pm 82,84)(p=0.000), L D L(m g / d l)$ $(249,93 \pm 45,43)(127,11 \pm 46,52)(\mathrm{p}=0.000)$ and CRP $(\mathrm{mg} /$ L) $(3,37 \pm 4,16)(1,43 \pm 1,96)(p=0.014)$ levels were significantly different between the $\mathrm{FH}$ and control groups respectively (Table 1).

The ultrasound imaging of liver of the two groups were similar. NAFLD was seen at 12 of 39 individuals in the control group. It was seen at 16 of 30 persons in the FH group ( $p=$ 0,058) (Table 2).

\section{DISCUSSION}

This is the first study to evaluate NAFLD in patients with $\mathrm{FH}$.

Fatty liver frequency was not found different among $\mathrm{FH}$ and control groups. High serum triglyceride levels and low serum HDL levels are seen at about $50 \%$ of patients with NAFLD [10].

In this study CRP concentrations ( $\mathrm{mg} / \mathrm{L})$ in $\mathrm{FH}(3.37 \pm 4.16)$ were significantly high from control group $(1.43 \pm 1.96)(p=$ 0.014). CRP concentrations in patients with $\mathrm{FH}$ were found significantly higher than control group in numerous studies $[11,12]$. CRP levels were associated with the presence of cardiovascular disease in $\mathrm{FH}$ patients [13]. Systemic inflammation induced by hypercholesterolemia may facilitates the progression to steatohepatitis.

In this study, triglyceride and HDL levels weren't significantly different between groups. Overproduction of VLDL (verylow-density lipoprotein) particles is an important cause of familial combined hyperlipidemia and it is driven by the amount of hepatic fat [14]. Increased VLDL and relatively normal levels of LDL secretion takes place in the hepatic steatosis at insulin resistance [15]. NAFLD patients exhibited significantly reduced HDL compared to the control subjects [16].

Sun et al. observed a significant association between LDL level and prevalence of NAFLD in 5689 subjects who had undergone liver ultrasonography. They have demonstrated that increased levels of LDL within the normal range have an independently relationship with an elevated risk of NAFLD [17]. Unlike this study, our study includes only the individuals who have $\mathrm{FH}$.

In a study, statistically significant high levels of serum triglyceride, LDL and HDL were found in the cases with NAFLD compared to the control group [18]. But in our study, there wasn't a significant difference at TG and HDL levels of the groups.

In the Multi-Ethnic Study of Atherosclerosis, LDL concentrations have generally been reported to be at normal levels in the setting of NAFLD [19].

It was shown that high cholesterol / high fat diets in some animal models caused steatosis in the liver and lesions of the aorta [20,21]. But that animals have lipid metabolism different from that of humans.

In this study, FH group didn't show any important difference from control group in the terms of NAFLD.

The limitation of this study is that the sample size is small. 


\section{CONCLUSION}

There isn't a significant difference between $\mathrm{FH}$ and control groups in the terms of NAFLD. The absence of NAFLD on ultrasonography, should not reduce the severity and importance of $\mathrm{FH}$, and the treatments should be made to prevent complications such as atherosclerosis.

\section{DECLARATION OF CONFLICT OF INTEREST}

The authors received no financial support for the research and/or authorship of this article. There is no conflict of interest.

\section{REFERENCES}

1. Defesche JC, Gidding SS, Harada-Shiba M, Hegele RA, Santos RD, Wierzbicki AS. Familial hypercholesterolaemia. Nat Rev Dis Prim 2017; 7: 17093. (doi: 10.1038/nrdp.2017.93).

2. Benedict $M$, Zhang $X$. Non-alcoholic fatty liver disease: An expanded review. World J Hepatol 2017; 9: 715-32. (doi: 10.4254/wjh.v9.i16.715).

3. Younossi ZM, Blissett D, Blissett R, Henry L, Stepanova M, Younossi $Y$, et al. The economic and clinical burden of nonalcoholic fatty liver disease in the United States and Europe. Hepatology 2016; 64: 1577-86. (doi: 10.1002/hep.28785).

4. Parekh S, Anania FA. Abnormal Lipid and Glucose Metabolism in Obesity: Implications for Nonalcoholic Fatty Liver Disease. Gastroenterology 2007; 132: 2191 207. (doi: 10.1053/j.gastro.2007.03.055).

5. Rader DJ, Hobbs $\mathrm{HH}$. Disorders of Lipoprotein Metabolism. In: Harrison's Principles of Internal Medicine, LongoDL. Harrison TR, et al (eds). 18th ed. New York, NY: McGraw-Hill Medical; 2012: Chapter 356.

6. Abdelmalek MF, Diehl AM. Nonalcoholic Fatty Liver Diseases and Nonalcoholic Steatohepatitis. In: Harrison's Principles of Internal Medicine, Longo DL. Harrison TR, et al (eds). 19th ed. New York, NY: McGraw-Hill Medical; 2019; Chapter 364.

7. Theise ND. Liver and gallbladder. In: Robbins \& Cotran Pathologic Basis of Disease, Kumar V, Abbas A, Aster J (eds). 9th ed. Philadelphia, PA: Elsevier Saunders; 2015; 845-6.

8. McCullough AJ. The clinical features, diagnosis and natural history of nonalcoholic fatty liver disease. Clin Liver Dis 2004; 8: 521-33. (doi: 10.1016/j.cld.2004.04.004).
9. Saadeh S, Younossi ZM, Remer EM, et al. The utility of radiological imaging in nonalcoholic fatty liver disease. Gastroenterology 2002; 123: 745-50. (doi: 10.1053/gast.2002.35354).

10. Assy N, Kaita K, Mymin D, Levy C, Rosser B, Minuk G. Fatty infiltration of liver in hyperlipidemic patients. Dig Dis Sci 2000; 45: 1929-34. (doi: 10.1023/a:1005661516165).

11. Gokalp D, Tuzcu A, Bahceci M, Arikan S, Pirinccioglu AG, Bahceci S. Levels of proinflammatory cytokines and hsCRP in patients with homozygous familial hypercholesterolaemia. Acta Cardiol 2009; 64: 603-9. (doi: 10.2143/AC.64.5.2042689).

12. Nambi V, Ballantyne CM. Utility of statin therapy using high-sensitivity C-reactive protein as an indicator of coronary heart disease risk. Curr Atheroscler Rep 2005; 7: 22-8. (doi: 10.1007/s11883-005-0071-8).

13. Cheng HM, Ye ZX, Chiou KR, Lin SJ, Charng MJ. Vascular stiffness in familial hypercholesterolaemia is associated with C-reactive protein and cholesterol burden. Eur J Clin Invest 2007; 37: 197-206. (doi: 10.1111/j.13652362.2007.01772.x).

14. Brouwers MCGJ, Bilderbeek-Beckers MAL, Georgieva AM, van der Kallen $\mathrm{CJH}$, van Greevenbroek MMJ, de Bruin TWA. Fatty liver is an integral feature of familial combined hyperlipidaemia: relationship with fat distribution and plasma lipids. Clin Sci 2007; 112: 123-30. (doi: 10.1042/CS20070314).

15. Choi SH, Ginsberg HN. Increased very low density lipoprotein (VLDL) secretion, hepatic steatosis, and insulin resistance. Trends Endocrinol Metab 2011; 22: 353-63. (doi: 10.1016/j.tem.2011.04.007).

16. Kirvar A, Ayaz T, Durakoglugil T, Baydur Sahin S, Sahin OZ, Durakoglugil E. The Association Between Non-Alcoholic Fatty Liver Disease with Carotid Intima Media Thickness. The Journal of Kartal Training and Research Hospital 2015; 26: 13-8. (doi: 10.5505/jkartaltr.2015.13284).

17. Sun D-Q, Liu W-Y, Wu S-J, et al. Increased levels of lowdensity lipoprotein cholesterol within the normal range as a risk factor for nonalcoholic fatty liver disease. Oncotarget 2016; 7: 5728-37. (doi: 10.18632/oncotarget.6799).

18. Imamoglu M. Classification of Hepatosteatosis with Ultrasonography and Analysis of the Effect of Hepatosteatosis Degree. Medical Journal of Mugla Sitki Kocman University, 2015; 2: 23-8. 
19. DeFilippis AP, Blaha MJ, Martin SS, et al. Nonalcoholic fatty liver disease and serum lipoproteins: The MultiEthnic Study of Atherosclerosis. Atherosclerosis 2013; 227: 429-36. (doi: 10.1016/j.atherosclerosis.2013.01.022).

20. Lee $L$, Alloosh M, Saxena $R$, et al. Nutritional model of steatohepatitis and metabolic syndrome in the Ossabaw miniature swine. Hepatology 2009; 50: 56-67. (doi: 10.1002/hep.22904).
21. Wouters K, van Gorp PJ, Bieghs V et al. Dietary cholesterol, rather than liver steatosis, leads to hepatic inflammation in hyperlipidemic mouse models of nonalcoholic steatohepatitis. Hepatology 2008; 48: 47486. (doi: 10.1002/hep.22363). 